\title{
A Review of the Academic Debate about United Nations Security Council Reform
}

\author{
Bjarke Zinck Winther \\ Ph.D. Fellow / Lecturer, Kroghstræde 3, Room 5-238, Aalborg University, \\ 9220 Aalborg Ø, Denmark \\ zinck@hum@aau.dk
}

\begin{abstract}
This article outlines and discusses the research on UNSC reform. The interdisciplinary field of UNSC reform research can be placed into two broad categories and four sub categories, each indicating the degree to which scholars believe in the benefits of either structural or working methods reform. These include topics such as legitimacy and efficiency and the question of (un)equal representation. The role of The Global South will feature heavily in analyses of how best to reform the UNSC, and of which actors or structures mainly prevent a reform from materialising. There has been a significant gap in research focusing on how the factors that feature as instruments of opposition, e.g. the presented benefits and detriments of the different approaches to reform, can potentially be converged to rethink the direction of the research.
\end{abstract}

\section{Keywords}

United Nations Security Council - United Nations reform - international relations international politics - history

\section{Introduction}

United Nations Security Council (UNSC) reform is one of the primary issues facing not only the council itself, but the entire field of international security, international relations, and the functioning of the international system 
at-large. ${ }^{1}$ The issue of reform is also one of the United Nations' (UN) "greatest challenges wherein all the difficulties and obstacles of wider institutional reform are collected together in a microcosm", ${ }^{2}$ and "is regarded by many inside and outside the UN as the most important and urgent issue of UN reform [...]". UN member states have debated reform since the UN's inception. This debate has recently been outlined by Bourantonnis, Blum, Swart \& Freiesleben, and Gowan \& Gordon. ${ }^{4}$ Nevertheless, little attention has been paid to a full review outlining the academic debate about UNSC reform, ${ }^{5}$ while exploring its underlying modes of thinking.

This article describes the academic debate's historical backdrop and examines more recent contributions to the topic, thereby illustrating that research in support of structural reform of the UNSC has gradually moved from being the prevailing emphasis toward taking up a smaller share of the dialogue. Consequently, a discrepancy exists between the debates among UN member states, where calls for structural reform make up the majority, ${ }^{6}$ and the

1 Jakkie Cilliers, "Global Trends Analysis," 2018; Sabine Hassler, Reforming the UN Security Council Membership (New York, NY: Routledge, 2013); Kai Schaefer, "Reforming the United Nations Security Council: Feasibility or Utopia?," International Negotiation 22, no. 1 (2017): 62-91, https://doi.org/10.1163/15718069-12341348.

2 Sven Bernhard Gareis, The United Nations An Introduction (Houndmills, Basingstoke, Hampshire: Palgrave Macmillan UK, 2012), 256.

3 Karen A Mingst and Margaret P Karns, The United Nations in the 21st Century, United Nations in the Twenty-First Century, 3rd ed., Dilemmas in World Politics (Boulder, Colo.: Westview Press, 2007), 242.

4 Dimitris Bourantonis, "The History and Politics of UN Security Council Reform," Security, 2005, https://doi.org/10.4324/9780203335390; Yehuda Z Blum, "Proposals for UN Security Council Reform," American Journal of International Law 99, no. 3 (2005): 632-49; Lydia Swart and Jonas von Freiesleben, Security Council Reform from 1945 to September 2013, 1st ed. (New York, NY: Center for U.N. Reform Education, 2013); Richard Gowan and Nora Gordon, "Pathways to Security Council Reform," Center on International Cooperation, no. May (2014): 39.

5 Bourantonnis' endnotes, Volacu's introductory description of how his article connects to the strands of UNSC reform inputs, and Nadin's 'select bibliography' - are the best examples of overviews, but neither of these sufficiently covers the lay of the land. Moreover, Luck also mentions the influence of academia as being an important, yet understudied aspect of SC-reform Edward C. Luck, "Reforming the United Nations: Lessons from a History in Progress," International Organizations and the Future, no. 1 (2003): 48, http://dspace .cigilibrary.org/jspui/handle/123456789/5935.

6 Saksena (1993) claims that one-hundred-and-seventy-five member states have expressed a desire for a UNSC that structurally reflects today's world, and Zacher writes that "A considerable majority of UN members support an increase in permanent and non-permanent members, but the regional neighbours of some perspective members [the UfC] and some small states oppose the addition of permanent members" Mark W Zacher, "The Conundrums of International Power Sharing: The Politics of Security Council Reform," in The United Nations and Global Security, ed. Richard M Price and Mark W Zacher (New York: Palgrave 
academic literature covering the topic. Subsequently, more research is needed to help explain this inclination.

The article does not propose that scholars are obliged to direct their research to fit with the interests of nation states. However, research that covers an issue which significantly impacts global security must be attentive to the preferences of nation states. The arena of UN studies, expanding many fields, is closely tied to the diplomatic arena within the UN. ${ }^{7}$ For this reason, scholars should be careful not to drive a wedge between the production of knowledge in academia and the application of knowledge in diplomatic circles. This is particularly important if academics want to maintain the possibility of influencing global governance and policy creation. Weiss \& Wilkinson ${ }^{8}$ argue that there are several factors to consider regarding what contributes to policy creation and global governance. As a result of the mentioned interlinkage between UN-academia and UN-diplomacy, I am adding the UNSC reform debate to that list. Nevertheless, more research is needed to document precisely how these implied connections function. Finally, I propose that the task for UNSC reform

Macmillan, 2004), 217. However, as Swart (2015) has pointed out, the extent of support for any particular frame of structural reform is uncertain.

7 Edward C. Luck and Thomas G. Weiss both have professional UN attachments on their CV's. Colin Keating was president of the UN General Assembly in 1994-1995 and Mahbubnani has held the UNSC presidency on two occasions during his work as Singapore's permanent rep. to the UN. Thakur was once Assistant Secretary-General at the UN. Daws, Fassbender, and Nadin have also worked for the UN. Moreover, as has been pointed out by Fred Iklé, within multilateral negotiations bonds between the involved persons emerge, as well as cultures of negotiation. This common intellectual culture leads to a shared set of concepts and a common vocabulary and understanding Fred Charles Iklé, "Role of Emotions in International Negotiations," in International Negotiation. Actors, Structure/Process, Values, ed. Peter Berton, Hiroshi Kimura, and William Zartman (New York, NY: St. Martin's Press, 1999), 335-50. The diplomatic and academic debates about unsc reform both appear to fit with Iklés descriptions of the concerning intellectual culture and vocabulary. This becomes apparent for anyone who has had the time to read up on the scholarly literature as well as the statements and resolution proposals from the countries and alliance groups that are active in the debate. Again, my focus is not to prove the linkage between academia and diplomacy or how one arena affects the other. What I point out is, that since academics involved in the debate clearly write with the aim of influencing the process, it is fair to consider how the writings from academia might impact the process. James A Paul's brief exposition of the interlinkage between journalists, NGO's, think tanks, and the diplomatic realm can also be used to support my argument James A Paul, Of Foxes and Chickens-Oligarchy and Global Power in the UN Security Council (New York, NY: Rosa Luxemburg Stiftung, 2017), 147ff.

8 Thomas G. Weiss and Rorden Wilkinson, "The Globally Governed-Everyday Global Governance," Global Governance 24, no. 2 (2018): 193-210, http://search.ebscohost.com/login .aspx?direct=true $\& d b=$ edshol\&AN=edshol.hein.journals.glogo24.18\&site=eds-live. 
research going forward is to explore new approaches so that the academic debate avoids becoming as gridlocked as the one among UN member states.

\subsection{What Is UNsc Reform?}

Structural reform refers to charter amendment(s), e.g., change in the council's membership structure or delegation of the veto prerogative. On the other hand, working methods reform can be agreed on within the UNSC without charter amendments, as the council, according to article 30 of the UN charter, is master of its procedures. ${ }^{9}$

Working methods reform has been branded as the feasible solution to the council's challenges, ${ }^{10}$ and as the "unsexy cousin of the mainstream reform debate." ${ }^{11}$ What it habitually refers to are modes of increased corporation between the council and NGo's and/or experts, and to matters relating to the council's provisional rules of procedures. ${ }^{12}$ The question of the veto can complicate the structure/working methods compartmentalisation, because veto-reform is a structural issue. Re-delegation or removal of veto rights require charter amendment, but in principle the council could agree to codes of conduct concerning the veto, e.g., not to use it in the case of resolutions targeting genocide, without a charter amendment, ${ }^{13}$ which would be working methods reform.

The research about UNSC reform mostly relies on one of two overall rationales. Both encompass the primary foci of the debate, namely how to advance the council's legitimacy, ${ }^{14}$ effectiveness, and efficiency through reform. One perspective proposes that for the council to become a more legitimate organ

9 Karen A Mingst, Margaret P Karns, and Alynna J Lyon, The United Nations in the 21st Century, 5th ed., Dilemmas in World Politics (Boulder, Co: Westview Press, 2017), 58; Loraine Sievers and Sam Daws, The Procedure of the UN Security Council, Fourth edi (Oxford: Oxford University Press, 2014), 673.

$10 \quad$ Hassler, Reforming the UN Security Council Membership, 210.

11 Peter Nadin, UN Security Council Reform, UN Security Council Reform (Abingdon, Oxon: Rou, 2016), 95, https://doi.org/10.4324/9781315687254.

12 See Sam Daws and Sidney Bailey, The Procedure of the UN Security Council / Sydney D. Bailey and Sam Daws, ed. Sydney Dawson Bailey and Sam Daws, Elektronis (Oxford: Clarendon, 1998).The rules are guidelines for UNSC meetings, agendas, languages, voting, etc. and they are the basis for UNSC conduct despite never being formally adopted (Nadin, 2016, p. 95).

13 As proposed by France and Mexico in 2015.

14 Hurd (2008) notes that very little attention has been given to how legitimacy works or what it means in the studies of international relations. 
of global governance, a structural reform of its membership and/or its veto system is needed. Consequently, it is argued that structural reform will lead to improved effectiveness and efficiency, because the larger group of countries in the council will be able to calibrate regional and global perspectives with states' agendas in an enhanced and more representative way, and therefore come up with better-fitted resolutions.

The opposing rationale is that a structural reform which expands the council's membership entails the risk of degrading the council's effectiveness and efficiency. Therefore, proponents of working methods reform argue that more countries on the council means a higher number of unaccountable actors, and consequently, gridlocked negotiations. Accordingly, it is argued that reform should chiefly be about changes in how the council operates. The working methods proponents maintain that once the methods of the council have been improved, the council's effectiveness and efficiency will increase as a result. ${ }^{15}$ In the final analysis, the debate is about how opposing arguments are rooted in one of the two rationales.

Those who have the relevant diplomatic experience or have had the time to read up on the body of literature, know that UNSC reform itself is complicated and necessitates many considerations, as laid out by Sievers \& Daws in their 'concluding reflections. ${ }^{16}$ To include many of such nuances within a frame that provides an overview, I present the debate since $1993,{ }^{17}$ by dividing it into four types of advocacy for UNSC reform that each reflect a different level of attachment to either structural or working methods reform. What one also learns from following both the debate among countries and scholars, is that arguments for views on reform must be explained vis-à-vis UNSC-legitimacy, effectiveness, and efficiency, as well as the understanding of a Global North / a Global South divide. ${ }^{18}$

15 Structural reform targets the council's composition such as new permanent or nonpermanent members, whereas working methods looks for a change in procedural matters like increased transparency, coordination with the general assembly (GA), or change concerning voting and speaking procedures.

16 Sievers and Daws, The Procedure of the UN Security Council.

17 In 1993 the Open Ended Working Group on the Question of Equitable Representation on and Increase in the Membership of the Security Council and Other Matters Related to the Security Council was established.

18 The Global North connotes the relatively wealthy and industrialised metaphorical 'Global North', and that countries from this group have been favoured by globalisation Charles Jones, "Global North," in A Concise Oxford Dictionary of Politics and International Relations (Oxford University Press, 2018). The Global South connotes the emergence since the 1960's of a new and relevant part of the globe, disassociated from the then predominant East-West thinking. When speaking of The Global South, it often, and particularly in the context of UNSC reform, refers to poor countries acting together Charles Jones, "Global 
Focusing on major themes from a debate about an issue as intricate as the one in question, might be equivalent to an archaeologist applying an excavator to extract relics from a necropolis. ${ }^{19}$ However, allowing for a certain amount of generalisation for the sake of creating an overview provides the opportunity to compartmentalise the literature. As a result, it becomes apparent that specific issues possess the apex of the debate and that it is possible to treat the existing input from a variety of academic fields, e.g., International Relations, International Organizations, International Law, International Politics, as part of the same discussion. Following the analogy of archaeology, the insensitive archaeologist who digs up and presents clusters might at first miss out on the details of a weapon, jewellery and pottery that would otherwise be excavated individually and sensibly. Nonetheless, digging up these artefacts in a cluster will likely result in an immediate accumulation of artefacts, alongside a broader understanding of the positioning of graves in burying rituals, rather than detailed knowledge on ancient craftsmanship that could be uncovered by a sensible archaeologist who would use a trowel and brush to pick up one item after the other. In short, the following overview as analogously described above, presents four general types of reform advocacy as follows-tenacious and moderate advocacy for structural reform, and a tenacious and a moderate advocacy for working methods reform.

The mentioned typology of four advocacies is applied to the contemporary debate, meaning from 1993 onwards. The historical backdrop section starts from the UN's inception. Both sections display that the discussion has moved from reflecting a Cold War and ensuing East-West context, on to mainly reflecting a framework of postcolonial issues, e.g., a North-South angle. ${ }^{20}$ Concerning the proposed solutions, structural reform was more often suggested in the earlier literature, but preferences for a working methods focus has continuously been on the rise.

It was Wilcox \& Macy, ${ }^{21}$ who first framed the discussion as being about the question of structure or working methods. Thematically, this period saw a lot

South," in A Concise Oxford Dictionary of Politics and International Relations (Oxford University Press, 2018).

19 Term for an archaeological site with more than one grave at that particular site.

20 K.P. Saksena, Reforming the United Nations (London: SAGE Publications Ltd, 1993), 33.

21 Francis O Wilcox and Carl Milton Macy, Proposals for Changes in the United Nations, The Brookings Series on the United Nations (Washington, D.C.: Brookings Institution, 1955). 
of criticism of the veto system's lack of fairness, and of its incompatibility with UN ideals of democracy. ${ }^{22}$ Such critiques were part of arguments for both structural reform via suggested abolition of the veto, ${ }^{23}$ and of arguments for enlargement of the council to enhance geographical equity. ${ }^{24}$ Goodrich ${ }^{25}$ however, who problematised the veto system, suggested a working methods reform via increased informal cooperation among the veto powers. The notions of geographical equity and adequate representation were utilised to argue for structural reform. Two concepts that also feature heavily when the same argument is made today.

Padelfort ${ }^{26}$ and Fish Armstrong ${ }^{27}$ both argued that an enlargement of the council, and thereby increased equity/geographical representation, was necessary for the UNSC to sidestep the Cold War's detrimental impact on the council's ability to work. Hula ${ }^{28}$ on the other hand, did not think that any reform effort would let the UNSC sidestep the East-West antagonism because he saw the council as the Cold War's "main battleground".

The pressure on the council's diplomatic milieu, that which emerged from Cold War antagonisms, prompted scholars to remain pessimistic concerning the UN's future role and the prospect of reform. ${ }^{29}$ Hevesy $^{30}$ however, saw the $\mathrm{UN}$ as "the champion of organisational opposition to colonial rule", and thereby implied, that the UN as a whole would eventually be able to mend geopolitical conflicts and inequality - also with regards to UNSC reform. Generally, the period was shaped by a tendency to emphasise the need for structural reform.

22 Hans Kelsen, The Law of the United Nations: A Critical Analysis of Its Fundamental Problems, with Supplement (London: Stevens \& Sons, 1951); Leland Goodrich, "The UN Security Council: Inception, Record, and Causes of Its Decline," ed. Leland Goodrich, International Organization 12 (1958): 273-87; P Hevesy, "The Reform of the United Nations and the Transformation of the British Empire," ed. P Hevesy, Friedenswarte 54, no. 2 (1957): 139-45; Wilcox and Macy, Proposals for Changes in the United Nations; Hamilton Fish Armstrong, “U.N. on Trial," ed. Hamilton Fish Armstrong, Foreign Affairs 39, no. 3 (1961): 388, https://doi.org/10.2307/20029496.

Hevesy, "The Reform of the United Nations and the Transformation of the British Empire." Wilcox and Macy, Proposals for Changes in the United Nations; Fish Armstrong, "U.N. on Trial."

25 Goodrich, "The UN Security Council: Inception, Record, and Causes of Its Decline."

26 Norman J Padelford, "Politics and Change in the Security Council," International Organization 14, no. 3 (1960): 381-401.

27 Fish Armstrong, "U.N. on Trial."

28 Eric Hula, "The United Nations in Crisis," Social Research 27, no. 4 (1960): 387-420.

29 Arthur N Holcombe, Strengthening the United Nations, 1st ed. (Westport, Connecticut, 1957), 195 .

3o Hevesy, "The Reform of the United Nations and the Transformation of the British Empire." 
Still, Nicholas questioned the presumed connection between more members and increased efficiency. ${ }^{31}$

\subsection{Post-reform 1965 until Open-ended Working Group (oE WG) 1993}

The period following the 1965-reform included evaluations and explanations of that reform, but also calls for further reform. The reform in 1965 was an expansion of the council, i.e., a structural reform, from five permanent and six non-permanent members ${ }^{32}$ to, still five permanent members, but now ten non-permanent members. Bennet, ${ }^{33}$ viewed the UNSC-deadlock affected by the Cold War as a positive, arguing that it increased the responsibility assumed by the UN's General Assembly, a notion he relied on to promote working methods reform. Furthermore, Bennett's and Lall's input about the Cold War ${ }^{34}$ joined the less pessimistic understanding of the Cold War's impact on the council, a trend which appears to have resulted in fewer calls for structural reform.

Additionally, in this period the wording from the UN charter's article 23 that the UN should pay heed to equitable geographical representation developed into an essential phrase oft utilised to promote structural reform of the council. Teja ${ }^{35}$ pushed for structural reform to enhance geographical equity and viewed the recent reform as a result of smaller nations succeeding in accomplishing their agenda, whereby they had demonstrated their untapped potential as agents of change and progress. Consequently, he called for further increase in effective, equitable representation (structural reform) to face the major powers' reaction to the recent reform, which he argued, was to hold more informal meetings to disarm the influence of the increased membership. For Boyd, smaller nations remained insignificant, except in decreasing the council's authority. ${ }^{36}$ Critics of the 1965-reform, however, were

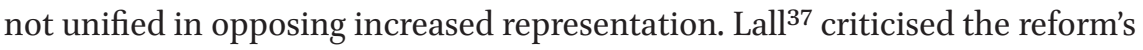

31 H.G. Nicholas, "The United Nations in Crisis," International Affairs 41, no. 3 (1965): $441-50$.

32 I use the terms non-permanent and electable interchangeably throughout the article.

33 A Leroy Bennett, "The Rejuvenation of the Security Council—Evidence and Reality," Midwest Journal of Political Science 9, no. 4 (1965): 361-75.

34 Bennett; Arthur S Lall, The Security Council in a Universal United Nations, Carnegie Endowment for International Peace. Occasional Paper, 11 (New York, 1971).

35 Jaskaran S Teja, "Expansion of the Security Council and Its Consensus Procedure," Nederlands Tijschrift Voor International Recht 16 (1969): 349-63.

36 Andrew Boyd, Fifteen Men on a Powder Keg: A History of the UN Security Council (London: Methuen \& CO Ltd, 1971), 112.

37 Lall, The Security Council in a Universal United Nations. 
mode of expansion and called for further regionalisation ${ }^{38}$ of the permanent seats to temper the USA-Soviet dominance of global politics. Hiscocks saw both the risk and reward caused by the recent structural reform, ${ }^{39}$ which was also the position of Baehr \& Gordenker ${ }^{40}$ who argued that expansion of seats increased the equity on the council but lowered its effectiveness.

A primary feature present in the period from 1965 until 1993 is the emerging problematisations of the council as being insufficiently representative of the world, and that increased membership might be detrimental to the council's ability to operate effectively.

\subsection{The Debate since the Initiation of the Open-ended Working Group (OEWG) in 1993}

Within the UN, the progress of reform was manifested with the establishment of the 'Open-ended Working Group on the Question of Equitable Representation on and Increase in the Membership of the Security Council' (OEWG) in $1993 .{ }^{41}$ The working group still exists, affirming its unappealing nickname 'the never-ending working group' ${ }^{42}$ In 2008 , the formal negotiations about UNSC reform transferred to the annually recurring rounds of informal talks ${ }^{43}$ in the 'Intergovernmental Negotiations' (IGN) ${ }^{44}$ Before this transition, in 2003, UN Secretary-General Kofi Annan had assembled a panel to report on threats, challenges, and change [to international security and peace] (H LP), ${ }^{45} \mathrm{a}$ report that included recommendations for a reform of the SC. Corresponding with, or perhaps inspired by the outlined development within the UN, more input from academia began emerging in the early 1990's.

The following typology outlines scholars' positions since 1993.

38 Regionalisation mainly refers to the provision of permanent council seats to countries that are understood as highly influential in their respective regions. Regionalization can also refer to increased attention to equal regional division of both types of seats. Richard Hiscocks, The Security Council (Plymouth: Clark, Doble \& Brendon Ltd, 1973).

40 Peter R. Baehr and Leon Gordenker, The United Nations — Reality and Ideal (New York, NY: Praeger Publisher, 1984).

41 Paul Taylor, Sam Daws, and Ute Adamczick, Documents on Reform of the United Nations / Edited by Paul Taylor, Sam Daws, Ute Adamczick, ed. Paul Taylor (Aldershot: Dartmouth, 1997), 416.

42 Thomas G. Weiss and Sam Daws, The Oxford Handbook on the United Nations, 1., vol. 1 (Oxford: Oxford University Press, 2007), 661, https://doi.org/10.1093/oxfordhb/ 9780199560103.001.0001.

43 If the GA decides for the negotiations to continue which has been the case since the IGN's initiation.

44 Lydia Swart, "Timeline of UN Security Council Reform," 2015.

45 Gro Harlem, Sadako Ogata, and Salim Salim, "Report of the UN Secretary-General's High Level Panel on Threats, Challenges and Change" 60231, no. December (2004). 


\section{Four Types of UNSC-reform Advocacy}

\subsection{Tenacious Advocacy for Structural Reform}

Structural reform is of the utmost importance and should be the foremost preference for securing and enhancing the council's validity. One of the most critical arguments concerns the allocation of seats to countries from the Global South. Also, it is contended that this course of action will amend a current sensation among many countries that the UNSC is an agent of the World War II victors and their national agendas. ${ }^{46}$

According to Langmore and Thakur, ${ }^{47}$ an unchanged and unchangeable membership of the council undermines its status and diminishes its authority and legitimacy. They propose that the elected members of the council should

46 Kishore Mahbubani, The Great Convergence: Asia, the West, and the Logic of One World (New York, NY: Public affairs, 2014); Madeleine O. Hosli and Thomas Dörfler, "The United Nations Security Council the Challenge of Reform," in Rising Powers and Multilateral Institutions, ed. D. Lesage and Van de Graaf T. (London: Palgrave Macmillan, 2015), 135-52, https://doi.org/https://doi.org/10.1057/9781137397607_8; Madeleine O. Hosli and Thomas Dörfler, "Why Is Change so Slow? Assessing Prospects for United Nations Security Council Reform," Journal of Economic Policy Reform 7870, no. September (2017): 1-16, https://doi .org/10.1080/17487870.2017.1305903; John Langmore and Ramesh Thakur, "The Elected but Neglected Security Council Members," Washington Quarterly 39, no. 2 (2016): 99-114, https://doi.org/10.1080/016366oX.2016.1204412; Joseph E. Schwartzberg, "Towards a More Representative and Effective Security Council," Political Geography 13, no. 6 (1994): 483-91, https://doi.org/10.1016/og62-6298(94)90037-X; Kishore Mahbubani, "Permanent and Elected Council Members," in The UN Security Council: From the Cold War to the 21st Century, ed. David Malone and M. David Boulder (London: Lynne Rienner, 2004), 253-66; Joseph E. Schwartzberg, "Entitlement Quotients as a Vehicle for United Nations Reform," Global Governance 9, no. 1 (2003): 81-114; Robert C. Johansen, "Enhancing the United Nations Peace-Keeping," in The Future of the United Nations System: Potential for the Twenty-First Century, ed. Chadwick F. Alger (Tokyo: United Nations University Press, 1998), 450; Peter Wallensteen, "Representing the World: A Security Council for the 21st Century," ed. Peter Wallensteen, Security Dialogue 25, no. 1 (1994): 63-75, https://doi.org/10 .1177/0967010694025001006; Madeleine O. Hosli et al., "Squaring the Circle? Collective and Distributive Effects of United Nations Security Council Reform," Review of International Organizations 6, no. 2 (2011): 163-87, https://doi.org/10.1007/s11558-011-9101-1; Vesselin Popovski, "Win-Win Formula for Reforming the UN Security Council," in The Global Community Yearbook of International Law and Jurisprudence 2015, ed. Giuliana Ziccardi Capaldo (Oxford: Oxford University Press, 2016); Mark A Boyer, Jonathan R Strand, and David P Rapkin, "Weighted Voting in the United Nations Security Council," ed. Mark A Boyer, Jonathan R Strand, and David P Rapkin, Simulation \& Gaming 42, no. 6 (2011): 772-802, https://doi.org/10.1177/1046878110365514; Richard Butler, "Reform of the United Nations Security Council," Penn State Journal of Law \& International Studies 1, no. 1 (2012): 23-39.

Langmore and Thakur, "The Elected but Neglected Security Council Members." 
be eighteen instead of the current ten seats and should remain in the council for three years instead of the current two. Mahbubani presents the question about achieving a structural reform as being one between the council keeping its current composition, and as a result losing its credibility, or, changing its structure and gaining credibility. ${ }^{48}$ Mahbubani's tenacity in pointing to the severe need for a structural reform that includes expansion of the permanent membership is underscored by his warning that "the continuing efforts of the $\mathrm{P}_{5}$ to retain their absolute dictatorial power amounts to folly".49 (2014, p. 116). This folly, Mahbubani argues, can eventually lead to a political storm that will sweep out the system of permanent SC members (p. 239). Consequently, Mahbubani proposes a new council that consists of seven permanent members, seven semi-permanent members (selected from a group of the same twenty-eight countries every other year), and seven electable members from the rest of the UN membership (p. 244). Popovski (2016) makes a similar suggestion with eight seats in the same three categories.

Also, within the category of tenacious structural reform advocacy are analyses of the current voting system and proposals for change therein. Boyer et al. (2011) and Dervis (2005) represent the track of thought which focuses on improving the council's operability via (a structural) reform of the voting system. Nonetheless, the rationale of Boyer et al., and Dervis' arguments qualifies as structural reform advocacy because abolishment of the current veto system, and formal changes to how voting is conducted in the council, require charter amendments. Their calls are tenacious because they emphasise that the council currently promotes unfair power relations. Moreover, structural reform is the only way that this immoral arrangement can be amended or toned down.

What binds the positions of this category together is an emphasis on the utmost need for change in the structure of the council. Also essential within this thinking, is the notion that working methods reform, if undertaken without structural reform, carries with it a severe defect. This is caused by not counterbalancing what is seen as an unfair and therefore untenable current structure of the SC, one that needs a more balanced geographical representation. ${ }^{50}$

48 Mahbubani, The Great Convergence: Asia, the West, and the Logic of One World; Kishore Mahbubani, "Council Reform and the Emerging Powers," in The UN Security Council in the 21st Century, ed. Sebastian Von Einsedel, David M Malone, and Bruno Stagno Ugarte (London: Lynne Rienner, 2016), 157-74.

49 Mahbubani, The Great Convergence: Asia, the West, and the Logic of One World.

5o Hosli and Dörfler, "Why Is Change so Slow? Assessing Prospects for United Nations Security Council Reform," 13; Wallensteen, "Representing the World: A Security Council for the 21st Century," 64; Butler, "Reform of the United Nations Security Council." 
The tenacious advocacy for structural reform also contains variations in evaluations of the feasibility of structural reform. In their final analyses, proponents for this mode of reform envision serious opposition from certain countries, yet structural reform is still viewed as ultimately being achievable. Hosli (2011), presents structural reform as an arduous challenge, whereas Poposvski (2016) and Mahbubani (2014) present structural reform as inevitable. Popovski argues that reform will occur, because it will be of benefit to all UN member states, and Mahbubani argues that structural reform is the inescapable choice if the countries sitting at or near the top of the current global power structure wish to remain relevant actors in the structure of global governance. Langmore and Thakur (2016) are also optimists, perhaps because they leave veto-reform out of their proposal. Whether veto-reform is viewed as harder to achieve than an expanded membership is hard to say. Johansen (1998), Wallensteen (1994), Swartzberg (1994), Boyer et al. (2011), and Dervis (2005) all support the abolishment of the veto system in the name of democracy. Out of these, only Swartzberg engages in a thorough defence of his proposal's chances of success. He argues, that pressure on the current veto holders to give up their prerogative, will increase and succeed as a result of other less challenging reforms within the UN system. All in all, the arguments that tenaciously call for structural reform are connected by a sense of urgency and exclusive priority, but the tenacious position contains variations when it comes to perceptions of chances of success and prioritisation of reforming the veto system.

\subsection{Moderate Advocacy for Structural Reform}

Another type of advocacy for structural reform subsists. This type generally agrees with the tenacious type that the Global South should be better represented on the council. What makes this a moderate position in favour of structural reform is the inclination to refrain from adopting a "structure before all" thinking as found in the tenacious arguments. Moderate structural reform advocacy broadly recognises that achieving structural reform will be very difficult and appreciates the potential rewards found in working methods approaches. Yet, the rationales of this category can still best be treated as in favour of a structural reform, albeit moderate, because, ultimately, structural reform, it is argued, should be prioritised over working methods reform. ${ }^{51}$

51 Bourantonis, "The History and Politics of UN Security Council Reform"; Anne-Marie Slaughter, "Security, Solidarity, and Sovereignty: The Grand Themes of UN Reform," American Journal of International Law 99, no. 3 (2005): 619-31; Bruce Russett, Barry O’Neill, and James Sutterlin, "Breaking the Security Council Restructuring Logjam," Global 
Fassbender's point about the futility of any reform not written into the charter ${ }^{52}$ is an appropriate introductory point for moderate structural reform arguments. Fassbender's position reflects a consciousness concerning both the challenging aspect of changing the UNSC membership and the benefits that changes in the working methods might bring about. He maintains that reform must be implemented in the charter to avoid being revoked according to powerful states' preferences. Knight argues that reform should target increased council transparency and democracy (both of which can be achieved without changing the structure of the council). In his final analysis, he puts forth that veto change or addition of permanent members might affect the council's ability to operate, and therefore, only the addition of non-permanent members should occur. This being "A more modest strategy" in his own words. ${ }^{53}$ Knight is focused on making the council less elitist and more representative, a notion which is backed by Bourantonnis. ${ }^{54} \mathrm{He}$ concludes his exposition of the historical process of UNSC reform negotiations by suggesting that if the council fails to update in accordance with contemporary geopolitical realities, alienation and crises between the council and the UN membership will ensue.

Russett et al., propose that inadequate representation on the council must be thought of, not only vis-à-vis the Global South, but also with regards to the countries that are most capable and willing to contribute economically to the UN, i.e., Japan and Germany. ${ }^{55}$ Russet et al.'s suggestion for structural reform is moderate because they consider added permanency and veto rights as not only non-attainable but also as and non-preferable. A stance which leads them to suggesting expansion of the non-permanent seats from ten to sixteen, combined with the introduction of re-election for those seats.

Governance 2, no. 1 (1996): 65-80; Bardo Fassbender, UN Security Council Reform and the Right of Veto: A Constitutional Perspective, Legal Aspects of International Organization, 32 (The Hague: Kluwer Law International, 1998); W Andy Knight, "The Future of the UN Security Council: Questions of Legitimacy and Representation in Multilateral Governance," in Enhancing Global Governance: Towards a New Diplomacy?, 2001, 19-37; Justin Morris, "UN Security Council Reform: A Counsel for the 21st Century," Security Dialogue, 2000, https://doi.org/10.1177/o967010600031003002.

52 Fassbender, UN Security Council Reform and the Right of Veto: A Constitutional Perspective, 346.

53 Knight, "The Future of the UN Security Council: Questions of Legitimacy and Representation in Multilateral Governance," 34.

54 Bourantonis, "The History and Politics of UN Security Council Reform."

55 Both of which have been favorites for obtaining increased representation on the council for some years (albeit their time as favorites have come to pass according to Swart \& Freiesleben (2013, p. 21) Japan and Germany contributes the second and third most to the UN budget respectively). 
Calls for changes to the veto system is not central to moderate structural reform advocacy. Slaughter, ${ }^{56}$ for example, suggests that an expansion of the non-permanent seats is a way for the global community of states to face down the usage of the veto from permanent members. She argues that this kind of expanded membership enables influence that corresponds to a global public opinion via the increase in represented states. Blum agrees, and contends that it will be harder for veto powers to halt resolutions that come forth with broad support. ${ }^{57}$ Fassbender ${ }^{58}$ however, believes that the veto system must be directly and not informally reformed. From a legal standpoint, he challenges proposals for a reform of the veto that is based on informal agreements between the $\mathrm{P}_{5}$ about abstaining from using their veto on specific resolutions. This approach, Fassbender argues, is grounded in an incorrect reading of the charter's stipulations about voting procedures in the Security Council (Article 27. Par. 3) which states that an affirmative vote is needed from nine members, including the concurring votes of the $\mathrm{P}_{5}$. Consequently, Fassbender believes that the charter and its call for the council to maintain international peace can be the starting point of veto reforms. He believes that structural, i.e. charter based reform of the veto usage from $\mathrm{P}_{5}$ states involved in the issue targeted by the resolution at hand, should be pursued as way to maintain peace and prevent conflict and thereby uphold the charter.

Morris $^{59}$ also focuses on how structural reform should be about impactful representation over moral representation. His position signifies the backbone of the moderate call for structural reform, namely, that structural reform is a moral responsibility for the UN and the global society to achieve, but also, that decision-makers should be aware that certain kinds of structural reform might result in unwanted consequences.

The moderate type of advocacy for structural reform is characterised by how proponents acknowledge the same issues as the tenacious type, i.e., the need for broader representation of countries and regions on the council. It is a different position being that the value of working methods reform is generally recognized. Additionally, caution about potential caveats of certain approaches to structural reform exists.

$5^{6}$ Slaughter, "Security, Solidarity, and Sovereignty: The Grand Themes of UN Reform."

57 Blum, "Proposals for UN Security Council Reform."

$5^{8}$ Fassbender, UN Security Council Reform and the Right of Veto: A Constitutional Perspective.

59 Justin Morris, "UN Security Council Reform A Council for the 21st Century," Security Dialogue 31, no. 3 (2000): 265-77. 


\subsection{Tenacious Advocacy for Working Methods Reform}

The underlying thinking of scholars' calls for working methods reflects that structural reform might satisfy many countries' desire for a council with increased global representation. Nevertheless, it is argued, such an approach will most likely be detrimental to the council's ability to operate and deliver results. The tenacious version of working methods advocacy emphasises the potential detriments of structural reform, and almost exclusively acknowledges working methods as the sound path toward worthwhile reform. ${ }^{60}$

When criticising arguments for structural reform, working methods reform advocates mainly focus on the disadvantages of UNSC expansion. The veto system plays a smaller role, yet still factors in as part of what working methods proponents want to change. Caron, ${ }^{61} \mathrm{Cox},{ }^{62}$ and Nadin, ${ }^{63}$ argue for a reform of the veto arrangement through a working methods approach, i.e., without charter amendments. Cox and Nadin both propose that the veto should be changed via informal agreements between the veto powers about the restriction of veto usage. Additionally, Caron believes, that the charter, as it stands, contains untapped potential to prevent an existing practice he calls 'the reverse veto',

6o Nadin, UN Security Council Reform; Seryon Lee, "The Feasibility of Reforming the Un Security Council: Too Much Talk, Too Little Action?," Journal of East Asia and International Law 4, no. 2 (2011): 405-18; Brian Cox, "United Nations Security Council Reform: Collected Proposals and Possible Consequences," South Carolina Journal of International Law and Business 6, no. 1 (2009): 1-36, http://scholarcommons.sc.edu/scjilb\%5Cnhttp://scholar commons.sc.edu/scjilb/vol6/iss1/4\%5Cnhttp://www.cnn.com/2009/BUSINESS/o1/28 /davos.wef.annan/index.html\%5Cnhttp://www.un.org/largerfreedomi/chap5.htm.; Schaefer, "Reforming the United Nations Security Council: Feasibility or Utopia?"; Ryan Davis, "An Unrealistic Proposal: An Argument Agaist The Enlargement of the United Nations Security Council," International Affairs Review 19, no. 1 (2010): 19-41, http:// www.iar-gwu.org/sites/default/files/articlepdfs/An Unrealistic Proposal.pdf; Hassler, Reforming the UNSecurity Council Membership; Colin (FES New York) Keating, "Reforming the Working Methods of the UN Security Council: The Next ACT" (New York, NY, 2011); Lauri Mälksoo, "Great Powers Then and Now: Security Council Reform and Responses to Threats to Peace and Security," in United Nations Reforn and the New Collective Security, ed. Peter G Danchin and Horst Fischer (Cambridge: Cambridge: Cambridge University Press, 2010), 94-113; Christian Wenaveser, "Working Methods: The Ugly Duckling of Security Council Reform," in The UN Security Council in the 21st Century, ed. Sebastion Von Einsiedel, David M. Malone, and Brunie Stagno Ugarte (London: Lynne Rienner, 2016), 175-94.

61 David D. Caron, "The Legitimacy of the Collective Authority of the Security Council Author," American Journal of International Law 87, no. 4 (1993): 552-88.

62 Cox, "United Nations Security Council Reform: Collected Proposals and Possible Consequences."

63 Nadin, UN Security Council Reform. 
which is when the veto is used to avoid alteration or ending of ongoing UNSC backed missions. ${ }^{64}$ Davis $^{65}$ also views the veto system as problematic and fundamentally unfair. But whereas Caron, Cox, and Nadin want informal changes to the veto system, Davis argues, that instead of focusing on membership or the veto, more attention should be paid to increasing transparency concerning interactions and connections within the council, and to reducing the number of resolutions that initiates military interventions. Such approaches to reform, Davis argues, will increase the council's credibility.

The tenacious advocacy for working methods reform often contains proposals that are more generic than they are precise, e.g., calls for better corporation with NGO's, or the mentioned calls for informal agreements that limit the use of the veto. There is more precision in the critical claims about structural reform, particularly that expansion of electable seats, permanent seats, and veto rights will hamper the council's ability to function. Both Caron's, Cox's, Davis', and Nadin's dispositions towards reform via enlargement is comprised in Cox's claim that: "As such, equitable geographical representation should not be sought in reforming the Council. Permanent regional seats, whether held by organizations or states for no reason other than geographical equity, skew the purpose of the council away from preventing a world war." 66

The aversion against structural reform is the pillar that sustains the tenacious calls for working methods reform, and it is often supported by the argument that working methods is the obtainable reform approach. ${ }^{67}$ Hassler and Nadin also both see structural reform as an answer, not to what the global community needs, but to states' national interest. They agree that, unfortunately, reform via structural expansion has become an ingrained discourse within the diplomatic sphere of multinational negotiations on the matter. ${ }^{68}$

Hassler adds to the critique of structural reform thinking by pointing out the unpredictability of geopolitics. She argues that an expanded USNC that satisfies much of the membership via the presence of recently emerged regional powers might in the future face the same calls for reform, due to fluctuations

64 Caron, "The Legitimacy of the Collective Authority of the Security Council Author," 556.

65 Davis, "An Unrealistic Proposal: An Argument Agaist The Enlargement of the United Nations Security Council."

66 Cox, "United Nations Security Council Reform: Collected Proposals and Possible Consequences," 22.

67 Hassler, Reforming the UN Security Council Membership, 84; Nadin, UN Security Council Reform, 113 .

68 Nadin, UN Security Council Reform, 117; Hassler, Reforming the UN Security Council Membership, 234. 
of global power and influence. ${ }^{69}$ The tenacious advocacy for working methods reform is essentially a warning voice against what is seen as the false hope associated with a structural reform approach, ${ }^{70}$ and moreover, as a cluster of arguments for why working methods reform is realistic. ${ }^{71}$ Structural reform, it is argued, offers only a false hope because it is unlikely to happen, and because a council with more will heighten the current council's problems.

\subsection{Moderate Advocacy for Working Methods Reform}

The moderate position echoes the tenacious working methods arguments when it comes to emphasising working methods reform. Yet two overall types of arguments dominate the moderate calls for working methods reform, both of which distinguishes this advocacy from the tenacious working methods advocacy. First, the rhetoric utilised to describe the consequences of structural reform is less critical than that which is found in the tenacious arguments for working methods reform. Second, within the cluster of moderate arguments, proposals for reforms often include both structural and working methods aspects, but not as an unwanted necessity, as seen in the tenacious arguments. Moderate working methods reformists generally appreciate that structural changes could benefit the council, yet, moderate calls for working methods contains scepticism towards unproven predictions about the positive consequences of structural reform. ${ }^{72}$

Weiss ${ }^{73}$ notes that structural reform will only temporarily appease the calls for greater inclusion in the council and that it, therefore, is not a sustainable path to reform. Weiss also agrees with the foundational point of tenacious working methods advocates, namely that enlargement would likely damage the

69 Hassler, Reforming the UN Security Council Membership, 132.

70 Davis, "An Unrealistic Proposal: An Argument Agaist The Enlargement of the United Nations Security Council," 37 .

71 Nadin, UN Security Council Reform; Keating, "Reforming the Working Methods of the UN Security Council: The Next ACT."

72 IanHurd,"MythsofMembership:ThePoliticsofLegitimationinUNSecurityCouncilReform," Global Governance 14, no. 2 (2008): 199-217; Edward C. Luck, Un Security Council-Practice and Promise-, Routledge, vol. 1, 2006, https://doi.org/10.1017/CBO9781107415324.004; Thomas G. Weiss, "The Illusion of UN Security Council Reform," The Washington Quarterly 26, no. 4 (2003): 147-61, https://doi.org/10.1162/0163660o3322387163; Thomas G. Weiss and Karen E. Young, "Compromise and Credibility: Security Council Reform?," Security Dialogue 36, no. 2 (2005): 131-54, https://doi.org/10.1177/0967010605054632; Thomas G Weiss, “A Pipe Dream? Reforming the United Nations," ed. Thomas G Weiss, Harvard International Review 33, no. 1 (2011): 48.

Weiss, "The Illusion of UN Security Council Reform." 
councils' functionality. ${ }^{74}$ Also, Luck echoes one of the tenacious camp's central points, stating that it will be very difficult to accommodate everyone when it comes to wishes for a changed UNSC structure. ${ }^{75}$ Further, Luck argues that if the current council, with its present working methods, are not sufficiently maintaining global peace, it cannot be expected that an enlarged council can do so. ${ }^{76}$ Weiss sees charter reform (i.e., structural reform) as a distraction from the more important discussions about the council, calling for evolutionary change and not revolutionary change, ${ }^{77}$ and restraint before urgency. ${ }^{78}$

Luck signifies the central stance of the moderate advocacy for working methods reform more than Weiss. He sees the disagreements among states concerning structural reform as having documented that the council's working methods must be reformed first, perhaps leading to later structural reforms e.g. more elected members. ${ }^{79}$ Luck portrays structural reform as potentially beneficial but situated below working methods reform on a list of priorities. In recognising the value of eventual structural reform, Luck's understanding and subsequent calls for structural reform aspects do not belong in the same category (tenacious working methods advocacy) as those proposed out of necessity by Nadin and Hassler, ${ }^{80}$ as they share a more pessimistic understanding of the consequences from a structural reform.

Other moderate proposals for working methods reform come from Niemetz, ${ }^{81}$ who proposes that a reform should make the inclusion of civil society possible in the council's voting procedures, and from Hurd ${ }^{82}$ who applies a discourse analytical approach to challenge the logic found in calls for structural reform. Niemetz's and Hurd's main agendas include harsh criticism of calls for structural reform, but their theses are mostly trying to re-shape the discussion by

\footnotetext{
74 Weiss and Young, "Compromise and Credibility: Security Council Reform?," 2005.

75 Luck, "Reforming the United Nations: Lessons from a History in Progress."

76 Luck, UN Security Council-Practice and Promise.

77 Weiss, "The Illusion of UN Security Council Reform."

78 Thomas G Weiss, Thinking about Global Governance: Why People and Ideas Matter, ed. Thomas G Weiss (London: Routledge, 2011).

79 Edward C. Luck, "Reforming the Security Council-Step One: Improving Working Methods," 2005; Edward C. Luck, "The Security Council at Seventy: Ever Changing or Never Changing?", in The UN Security Council in the 21st Century, ed. Lynne Riener Publishers (Boulder, Co, 2016), 195-216.

8o Nadin, UN Security Council Reform; Hassler, Reforming the UN Security Council Membership.

81 Martin D. Niemetz, Reforming the UN Decision-Making Procedures: Promoting a Deliberative System for Global Peace and Security (Abingdon, Oxon: Routledge, 2015).

82 Hurd, "Myths of Membership: The Politics of Legitimation in UN Security Council Reform."
} 
introducing new dimensions to the debate, i.e., the inclusion of civil society and discourse analysis, not to chiefly oppose the value of structural reform. Blum's article ${ }^{83}$ is one that, along with many of Weiss's arguments, trends towards tenacious advocacy for working methods reform. She believes that a point exists, where the amount of new UNSC members would reach a critical mass and make the council too big to act. Besides, Blum rejects the notion that geographical representation should be an essential aspect of the reform process. Nonetheless, Blum realises that in the final analysis, a failed procedure of council enlargement will likely lead to failure in improved working methods as well. As a result, Blum is critical towards certain aspects of structural reform and warns of potential dangers attached to it but does not rule out that structural reform presents positive aspects.

Wouters and Ruys, subscribe to another string of argumentation. They call for emphases on accountability and democratic build-up in the council, and argue, that representation-focus [inclusion of more members] will not ensure that new members live up to the demands that come with being a council member or provide a better functioning council. ${ }^{84}$

Ultimately, the moderate advocacy for working methods reform ranges from Blum's and Weiss' criticism of structural reform, toward Hurds scepticism of the logic of arguments for structural reform, and to Blum and Luck's appreciation of the need for structural reform, in combination with working methods reform. All proponents of these types of reform calls are united in the prioritisation of working methods over the council's structure, and their scepticism towards the proposed benefits of structural reform.

\subsection{Summary}

Not all contributions point to a particular mode of reform. Schaefer ${ }^{85}$ and Mälksoo, ${ }^{86}$ for example, have written mainly to portray the challenges and, in their eyes, the bleak outlook for meaningful reform of the council. The central points from the four types of advocacy however, are present in most if not all literature concerned with UNSC reform. That is, whether or not the structure of the UNSC aligns, or should align, with principals of equity and with the geopolitical realities of today.

83 Blum, "Proposals for UN Security Council Reform."

84 Jan Wouters and Tom Ruys, "Security Council Reform: A New Veto for a New Century?," Military Law and Law of War Review, 2005, 164-66, https://doi.org/10.1525/sp.2007.54.1.23.

85 Schaefer, "Reforming the United Nations Security Council: Feasibility or Utopia?"

86 Mälksoo, "Great Powers Then and Now: Security Council Reform and Responses to Threats to Peace and Security." 
The answers found in both types of arguments for structural reform are constructed as normative propositions, ${ }^{87}$ arguing first and foremost, that principals of democracy and equality should be the central guides for how the international community approaches UNSC reform. On the other side of the main dividing line, arguments in favour of working methods are based more on pragmatic considerations. Working methods proponents argue that the council was created to serve a function, and how that task is best fulfilled ought to be the primary guide for those discussing UNSC reform. In short, structural reform arguments are based on calls for the council's alignment with contemporary geopolitical realities, whereas working methods reform arguments are based on precautions against this.

Many authors will not appreciate the claim that their arguments are chiefly based on a distinctive normative or pragmatic approach. They will argue that their analyses and proposals encompass both aspects. How proponents for both kinds of UNSC reform include the normative and the pragmatic dimension, while still emphasising mainly one, is through how they present causality as going from one to the other, via the terms legitimacy, effectiveness, and efficiency, which are concepts that in themselves represent essential aspects of the debate in question.

\section{Legitimacy, Effectiveness, Efficiency}

To be effective, international governance must be concentrated in some body other than the whole. The question is how to design this body so that the governed as a whole, both in fact and in perception, are served rather than oppressed. ${ }^{88}$

Caron's statement showcases the core of what is discussed, when language about the legitimacy, effectiveness, and the efficiency of the council is utilised. Effectiveness refers to the ability to produce the expected outcome, and efficiency refers to the same, but with an emphasis on doing it without wasted efforts or resources. These two terms are used interchangeably in the debate, but they always refer to the council's ability to perform its task-the maintenance of peace [henceforth: effectiveness/efficiency = efficiency]. When it comes to legitimacy, what is often referred to, is what Caron coins as the perception of being served rather than oppressed. Discussions about the

87 Zacher (2004) labels structural refom "the central normative issue" [of UN reform].

88 Caron, "The Legitimacy of the Collective Authority of the Security Council Author," 588. 
legitimacy of the council can refer to how countries and other actors evaluate the actions of the council, but mainly, legitimacy concerning UNSC reform is discussed when assessing whether the council in its composition sufficiently represents the body of UN member states.

The structural reform camp believes there is a decline in the UNSC's legitimacy, either as a consequence of unequal representation i.e., a structure that reflects 1945 and not today, ${ }^{89}$ or explained as a combination of unequal geographical representation and disappointing performance (inefficiency) from the council. ${ }^{90}$ One would perhaps expect that the majority of calls for working methods reform would point out that the status of the council's legitimacy is mainly a result of its unsatisfactory performance, such as non-intervention in contemporary conflicts, e.g. Syria and Crimea, and leave out that unequal representation influences legitimacy in a negative direction. Such theses exist, ${ }^{91}$ but mostly, the arguments for a working methods reform tend to appreciate that the council's lack of global representativeness is significant when explaining the apparent decrease in the council's legitimacy. ${ }^{92}$ Nonetheless, the majority of working methods proponents assert that an expanded membership, both permanent or non-permanent, in the long run, will impact the council's legitimacy negatively, because it would damage the council's ability to operate efficiently. 93

As mentioned earlier, both sides argue that their suggested mode of reform increases the UNSC's legitimacy and efficiency. The difference is found in how the causality between legitimacy and efficiency is portrayed. Structural reform

89 Schwartzberg, "Entitlement Quotients as a Vehicle for United Nations Reform," 81; Russett, O'Neill, and Sutterlin, "Breaking the Security Council Restructuring Logjam," 78; Mahbubani, The Great Convergence: Asia, the West, and the Logic of One World, 239; Hosli and Dörfler, "Why Is Change so Slow? Assessing Prospects for United Nations Security Council Reform," 1-2.

9o Langmore and Thakur, "The Elected but Neglected Security Council Members," 101-2; Matthew Gould and Matthew D. Rablen, "Reform of the United Nations Security Council: Equity and Efficiency," Public Choice 173, no. 1-2 (2017): 3, https://doi.org/10.1007/s11127 -017-0468-2; Mahbubani, "Council Reform and the Emerging Powers," 154.

91 Nadin, UN Security Council Reform; Davis, "An Unrealistic Proposal: An Argument Agaist The Enlargement of the United Nations Security Council."

92 Hassler, Reforming the UN Security Council Membership, 2. 80-84; Sebastian Von Einsiedel, David M. Malone, and Bruno Stagno Ugarte, "Conclusion: The Security Council and a World in Crisis," in The UN Security Council in the 21st Century, ed. Sebastian Von Einsiedel, David M. Malone, and Bruno Stagno Ugarte (Boulder, Co: Lynne Rienner, 2015), 827.

93 Nadin, UN Security Council Reform, 87; Keating, "Reforming the Working Methods of the UN Security Council: The Next ACT," 85-86; Einsiedel, Malone, and Ugarte, "Conclusion: The Security Council and a World in Crisis," 20; Hassler, Reforming the UN Security Council Membership, 116 . 
advocacy contends that increased legitimacy leads to more efficiency, ${ }^{94}$ i.e., "[a security council] that better reflects the geopolitical realities of today, would be more authoritative, and therefore more efficient". ${ }^{95}$ On the other hand, working methods advocacy see the inverse causality, namely that increased efficiency will lead to an increase in the council's legitimacy. ${ }^{96}$ Moreover, many who support a working methods reform, will criticise claims about how legitimacy, achieved via structural reform, will lead to efficiency. ${ }^{97}$ Hurd for example, is mainly critical towards the notion of causality from legitimacy to efficiency. ${ }^{98}$ Mälksoo goes further, favouring neither of the two overall modes of reform, he labels the idea of proposing even a correlation between the two concepts as "absurdly idealistic". 99

However, the majority view, found on both sides of the working methods/ structure divide, is reflected by Russet et al., in the claim that: "Ultimately, legitimacy and effectiveness depend substantially on each other". ${ }^{100}$ Related to the portrayal of how the legitimacy and efficiency of the council can be improved, there is also the discussion about whether and how an increased representation of The Global South can be manifested.

The UNSC must be restructured, to include a prominent member of the Global South. ${ }^{102}$

94 Langmore and Thakur, "The Elected but Neglected Security Council Members"; Mahbubani, "Council Reform and the Emerging Powers."

95 Louise Fréchette, "Adapting to the Twenty-First Century," in Irrelevant or Indispensable?: The United Nations in the Twenty-First Century, ed. Paul Heinbecker and Patricia Goff (Waterloo: Wilfrid Laurier University Press, 2005), 13.

96 Keating, "Reforming the Working Methods of the UN Security Council: The Next ACT"; Wenaveser, "Working Methods: The Ugly Duckling of Security Council Reform."

97 Hassler, Reforming the UN Security Council Membership; Wenaveser, "Working Methods: The Ugly Duckling of Security Council Reform"; Hurd, "Myths of Membership: The Politics of Legitimation in UN Security Council Reform."

98 Hurd, "Myths of Membership: The Politics of Legitimation in UN Security Council Reform."

99 Mälksoo, "Great Powers Then and Now: Security Council Reform and Responses to Threats to Peace and Security," 110.

100 Russett, O'Neill, and Sutterlin, "Breaking the Security Council Restructuring Logjam," 66.

101 Zifcak's work (2009) is a discussion of the North-South issues concerning UN reform in general.

102 Klaus Schlichtmann, "An Enduring Concept for Security Council Reform," Beijing Law Review 97 (2011): 106. 
Discussions about Global North-South relations, i.e., addressing the current imbalance, ${ }^{103}$ play essential roles in the reform-debate, often in combination with the legitimacy-efficiency aspect. Fassbender has explicated that states from the Global North generally prefer working methods reform, whereas countries from the Global South prefer structural reform. ${ }^{104}$ Zifcak reiterates this point in stating that "[...] the North's principal interests relate to matters of security and efficiency. The South's primary emphasis is on economic development and equity". ${ }^{105}$ Geopolitical North-South imbalance and the quandary of maintaining a stance which (in the eyes of the Global South) upholds historical injustices, is countered by working methods proponents, by the already mentioned complaint about the debate being too idealistic. It is argued, that it has become politically incorrect to speak against structural reform, even if it is seen as detrimental to council efficiency. ${ }^{106}$

Luck, a moderate working methods proponent, maintains that the cost of a reform which decreases inequality among states concerning UNSC representation could be a decline in the council's efficiency, as more countries would then have a say in matters where the current fewer countries cannot agree. ${ }^{107}$ Not only do working methods advocates point out the threat to the council's efficiency, as posed by enlargement, the case is also being made that expanding the council only serves as temporary appeasement to the states calling for this kind of reform. All countries part of - or identifying with - The Global South cannot become members. Eventually, Nadin argues, an enlarged council will again be perceived as an elitist club by those on the outside, ${ }^{108}$ and the legitimacy of the council, with regards to the notion of representation of the Global South, will not have been increased.

\footnotetext{
103 Sam Daws, "Security Council Reform: The Dual Risks," in Proceedings of the International Conference on UN Reform (Tehran, Iran, 2005), 1.

104 Bardo Fassbender, "Pressure for Security Council Refrom," in The UN Security Council. From the Cold War to the 21st Century., ed. David M Malone (London: Lynne Rienner Publishers, Inc, 2004), 341-55.

105 Spencer Zifcak, United Nations Reform: Heading North or South? (Abingdon, Oxon: Routledge, 2009), 170.

106 Hassler, Reforming the UN Security Council Membership, 3; Nico Schrijver, "Reforming the UN Security Council in Pursuance of Collective Security," Journal of Conflict and Security Law 12, no. 1 (2007): 134, https://doi.org/10.1093/jcsl/krmoo3; Schaefer, "Reforming the United Nations Security Council: Feasibility or Utopia?," 88.

107 Luck, "Reforming the United Nations: Lessons from a History in Progress"; Edward C. Luck, "How Not to Reform the United Nations," Global Governance: A Review of Multilateralism and ... 11, no. 4 (2005): 407-14, http://journals.rienner.com/doi/abs/10.5555/ggov.2005.11.4 .407; Luck, UN Security Council-Practice and Promise.

108 Nadin, UN Security Council Reform, 73-75.
} 
The response to notions of future changes in global power found in calls for structural reform is to suggest semi-permanent seats via potential repeating re-elections. ${ }^{109}$ Critique of this approach as a more attainable version of structural reform comes from structural reform proponent Schwartzberg. He notes that "semi-permanent" seats is a strategy based on an oxymoron, and not worth following. ${ }^{110}$ This view is also shared by tenacious working methods proponent Hassler, who points out that powerful nations would have an easier task set before them in gaining re-election, than smaller states' task of being elected.111

Regardless of how scholars are positioned concerning what kind of reform they propose and the significance attributed to a global North/South division, most of them also present explanations of why substantial reform has yet to occur.

Arguably, change happens even if reform does not, ${ }^{112}$ and the council is regularly updating its procedures, ${ }^{113}$ but not in a manner that has satisfied the calls for reform. This has been made apparent because calls persist for both kinds of reform. If it is possible for the council's working methods to undergo developments routinely, and if there is a widespread consensus among states about the need for reform, what then is holding up the process? Why are procedures not changed in manners that satisfy the vast body of UN member states' calls for reform?

One of the predominant explanations is to place the blame on the $\mathrm{P}_{5}$ countries. ${ }^{114}$ Observers of the debate might wonder why $\mathrm{P}_{5}$ states have

109 Mahbubani, The Great Convergence:Asia, the West, and the Logic of One World; Mahbubani, "Council Reform and the Emerging Powers"; Ramesh Thakur et al., "What Is Equitable Geographic Representation in the Twenty-First Century," 1999; Langmore and Thakur, "The Elected but Neglected Security Council Members."

110 Schwartzberg, "Towards a More Representative and Effective Security Council," 99.

111 Hassler, Reforming the UN Security Council Membership, 157.

112 Luck, "Reforming the United Nations: Lessons from a History in Progress," 48.

113 Schaefer, "Reforming the United Nations Security Council: Feasibility or Utopia?," 89; Nadin, UN Security Council Reform, 113 .

114 Mahbubani, The Great Convergence: Asia, the West, and the Logic of One World; Weiss, "The Illusion of UN Security Council Reform"; Weiss and Young, "Compromise and Credibility: Security Council Reform?," 2005; Weiss, “A Pipe Dream? Reforming the United Nations."; Thakur et al., "What Is Equitable Geographic Representation in the Twenty-First Century"; 
occasionally made public their recognition of the need for reform, and how this fits with the $\mathrm{P}_{5}$ seemingly being responsible for holding up the process. Explanations which identify the $\mathrm{P}_{5}$ as roadblocks respond to such objections by pointing to the difference between official and unofficial diplomacy. One example given by Mahbubani, is that China supports its fellow BRICs ${ }^{115}$ alliance members India and Brazil's campaigns for UNSC permanency, ${ }^{116}$ yet unofficially promotes discontent with the veto system. This is being done to strengthen the camp of reform voices that seeks abolition of the veto, inciting antagonisms within the debate and thereby preventing the process from progressing. ${ }^{117}$ Moreover, there is the consensus alluded to earlier, that official support of UNSC reform is mandatory, ${ }^{118}$ which explains why $\mathrm{P}_{5}$ states act in accordance with this culture publicly, while pursuing their real agenda behind the scenes.

Another explanation points out that the prospect for reform is prevented by regional rivalries. The $\mathrm{G}_{4}$, by many considered as main drivers for reform, is opposed by the UfC group, ${ }^{119}$ an alliance whose key agenda appears to be the prevention of $\mathrm{G}_{4}$ ascension to permanency. ${ }^{120}$ Generally, disagreements among countries about who should achieve more influence and how they should get it prevails, ${ }^{121}$ and national interests obscure countries' potential will to support reform proposals. ${ }^{122}$ Weiss, for example, who places $\mathrm{P}_{5}$ opposition at the top of the list of reasons for non-reform, acknowledges that "member

Ramesh Thakur, "United Nations Security Council Reform," African Security Review 13, no. 3 (2004): 66-74, https://doi.org/10.1080/10246029.2004.9627305; Langmore and Thakur, "The Elected but Neglected Security Council Members"; Gould and Rablen, "Reform of the United Nations Security Council: Equity and Efficiency."

115 Brazil, Russia, India, China, and South Africa.

116 “2014 Fortaleza Declaration," accessed March 20, 2019, http://www.brics.utoronto.ca/docs /140715-leaders.html.

117 Mahbubani, The Great Convergence: Asia, the West, and the Logic of One World, 239.

118 Schaefer, "Reforming the United Nations Security Council: Feasibility or Utopia?," 62.

119 Membership of this group is not always easy to know fully, but it is led by Italy and Pakistan and also includes Canada, Argentina, Colombia, Costa Rica, Malta, Mexico, South Korea, San Marino, Spain and Turkey.

120 Nadin, UN Security Council Reform; Swart and von Freiesleben, Security Council Reform from 1945 to September 2013. Hosli et al., "Squaring the Circle? Collective and Distributive Effects of United Nations Security Council Reform"; Fassbender, "Pressure for Security Council Refrom"; Bourantonis, "The History and Politics of UN Security Council Reform"; Zacher, "The Conundrums of International Power Sharing: The Politics of Security Council Reform."

121 Fassbender, "Pressure for Security Council Refrom," 344.

122 Nadin, UN Security Council Reform, 48. 
states of the Global South are unlikely to any agreement among themselves". ${ }^{123}$ No one attempts to negate the logic behind either the $\mathrm{P}_{5}$ or certain alliance groups being proposed as key actors of prevention. Authors tend to subscribe to one explanation over the other, but most recognise the validity of both.

Another explanation is that the UN system itself is perhaps the most significant hindrance factor, e.g., via the veto-system or the demand for a two-thirds majority in the GA for charter amendments. ${ }^{124}$

Luck has proposed that "[among academics] there is nothing close to a consensus diagnosis of what ails the council". ${ }^{125}$ I have argued that a tendency towards agreement, or at least the lack of entrenched positions, prevail when it comes to thoughts about what primarily causes a decrease in council-legitimacy (insufficient representation in relation to the geopolitical landscape), and about which (f)actors currently prevent reform ( $\mathrm{P}_{5}$ and regional rivalries). The central divide in the debate exists between the preferred two modes of reform.

Everyone wants a better functioning UNSC to the benefit of international relations and everyone hope for ensuing global peace. Ostensibly, there is a growing predisposition to propose that a better functioning council and the positive consequences thereof, is primarily achievable via a focus on efficiency through a working methods reform. This conviction leads to the negation of the wishes of, if not the majority then at least many UN member states, and encourages reform approaches which secludes structural change from being the reform mode through which improvement of the council is pursued. Still the emphasis on recommending working methods reform has not completely overtaken the academic debate, and the field to this day, remains well balanced. Nonetheless, continued research is needed, that from the outset, will seek to investigate how a structural reform could happen. This is a preferable alternative to fearing, as Klabbers points out, that a focus on structural reform might convey the notion that the council as a system does not work at all. ${ }^{126}$

123 Thomas G. Weiss and Karen E. Young, "Compromise and Credibility: Security Council Reform?," Security Dialogue 36, no. 2 (2005): 135, https://doi.org/10.1177/0967010605054632.

124 Hosli and Dörfler, "Why Is Change so Slow? Assessing Prospects for United Nations Security Council Reform"; Thomas G Weiss, What's Wrong with the United Nations and How to Fix It, 2. ed. (Cambridge: Polity press, 2012); Richard Falk, "The Outlook for UN Reform: Necessary, but Impossible," in Between Sovereignty and Global GovernanceThe United Nations, the State and Civil Society, ed. Albert J Paolini, Anthony P Jarvis, and Christian Reus-Smit (London: Macmillan Press, 1998), 359.

125 Luck, UN Security Council -Practice and Promise, 1:126.

126 Jan Klabbers, "The Politics of Institutional Reform," in United Nations Reforn and the New Collective Security, ed. Peter G Danchin and Horst Fischer (Cambridge: Cambridge: Cambridge University Press, 2010), 93. 


\section{$8 \quad$ Not Writing of Structural Reform-a Way Forward?}

All enlargement plans put forward to date are fundamentally flawed and offer a false hope of efficiency through representation. ${ }^{127}$

Davis' claim is harsh, but it reflects the notion of chances for structural reform being shaky, and that this belief is widespread. ${ }^{128}$ Nonetheless, in 1965 , a structural reform materialised despite strong opposition from powerful states, ${ }^{129}$ a precedent to keep in mind when judging what is possible. All else being equal, a structural reform necessitates a working methods reform, as the council then would need to adjust to a new size and therefore implement, e.g., new procedures for it voting processes. ${ }^{130}$ Thus, the potential benefits of a working methods reform can be considered a part of how the impact of structural reform is evaluated-structural reform can be a catalyst for working methods reform.

Focus on how aspects of the two kinds of reform can positively impact one another is present, ${ }^{131}$ but under-emphasised in the debate. Even though many propose reforms of both types, such theses do not start with a focus on seeking out mutually reinforcing dynamics. Nadin, ${ }^{132}$ a tenacious proponent for working methods reform, concludes his work by, reluctantly and out of necessity, suggesting reform models that include both structural and working methods aspects. However, he does not discuss if and how aspects of structural reform can impact the council's working methods.

Working methods proponents tend to downplay the positive potential in structural reform models. They fear "that deficits in working methods would be even more apparent in an expanded council". 133 Hassler sees structural

127 Davis, "An Unrealistic Proposal: An Argument Agaist The Enlargement of the United Nations Security Council," 37.

128 Weiss, "The Illusion of UN Security Council Reform"; Nadin, UN Security Council Reform; Fassbender, "On the Boulevard of Broken Dreams," International Organizations Law Review 2 (2005): 391-402; Hosli and Dörfler, "The United Nations Security Council the Challenge of Reform"; Hosli and Dörfler, "Why Is Change so Slow? Assessing Prospects for United Nations Security Council Reform."

129 Bourantonis, "The History and Politics of UN Security Council Reform," 28.

130 The process of agreeing on the 7oth GA IGN outcome, 'the elements of convergence' demonstrates that agreeing on what constitutes a majority and how such rules can transfer from the current (size of the) council to an enlarged council is not a simple matter.

131 Kemal Dervis and Ceren Ozer, A Better G Lobalization, 2005; Gould and Rablen, "Reform of the United Nations Security Council: Equity and Efficiency"; Ville Lättilä and Aleksi Ylönen, "United Nations Security Council Reform Revisited: A Proposal," Diplomacy and Statecraft 30, no. 1 (2019): 164-86, https://doi.org/10.1080/o9592296.2019.1557423.

132 Nadin, UN Security Council Reform.

133 Luck, UN Security Council -Practice and Promise, 1:122. 
reform as a possibility only after the implementation of working methods reform, not as a consequence, but as an add-on to appease those vying for increased representation. ${ }^{134}$ Blum, a moderate working methods advocate, notes a potential dynamic between the two modes of reform, but in a negative sense. She argues, that failed council enlargement will likely lead to failed improvements in working methods, ${ }^{135}$ but Blum does not explore such interconnections. Considerations about procedural benefits from structural reform, e.g., improved dynamics between permanent and non-permanent members, ${ }^{136}$ I believe, deserve a higher degree of attention in the debate.

The case for structural reform is closely tied to the notion of this mode being backed by many UN member states. Whether a majority of states essentially want a structural reform is debatable. Claiming it as fact necessitates the caveat that majority support likely only exists when it comes to an unspecified model of structural reform (where no one's rival ascends to higher places). If this were not the case, then a concrete reform resolution would probably have been put to the vote in the GA in recent years, which is a feat that not even the $\mathrm{G}_{4}$ has attempted. Still, scholars from both sides of the structure/working methods divide often mention structural reform as being supported by a majority of states. ${ }^{137}$

A strenuous critique of the structural reform advocacy is found mainly in the arguments coming from tenacious working methods proponents. Structural reform is called "a flawed approach", 138 "a widespread shortcoming",139 and an approach supported by "unsophisticated arguments". 140 The level of recognition within academia about the existence of at least a high level of support among UN member states for structural reform of the council, supports the need for continued efforts to investigate this path to reform. Such research

134 Hassler, Reforming the UN Security Council Membership, 202.

135 Blum, "Proposals for UN Security Council Reform," 648.

136 Mahbubani, "Permanent and Elected Council Members."

137 Weiss, "The Illusion of UN Security Council Reform"; Jonas von Freiesleben, "Reform of the Security Council," Governing and Managing Change at the United Nations 4 (2013): 1-22; Einsiedel, Malone, and Ugarte, "Conclusion: The Security Council and a World in Crisis," 866; Davis, "An Unrealistic Proposal: An Argument Agaist The Enlargement of the United Nations Security Council"; Langmore and Thakur, "The Elected but Neglected Security Council Members"; Zacher, "The Conundrums of International Power Sharing: The Politics of Security Council Reform," 217.

138 Davis, "An Unrealistic Proposal: An Argument Agaist The Enlargement of the United Nations Security Council," 36-37.

139 Schaefer, "Reforming the United Nations Security Council: Feasibility or Utopia?," 86.

140 Nadin, UN Security Council Reform, 72. 
could perhaps test if the presented critique is valid, or if specific approaches have yet to be investigated before they can be written off.

There is weighty truth to the argument often used in favour of working methods reform that the council must be an able body to uphold (pursue) international peace. Consequently, reform emphases cannot exclusively target increased representation, without paying heed to the risks of further tying the Gordian knot currently manifest, both in the reform process and in the performance of the council concerning crises like the Syrian Civil War. Still, more research is needed that seek to meet Paul's call for a united front (civil society, Academia, NGO's, and States) to increase the pressure for a transformative reform, even one that requires charter change. ${ }^{141}$

Sam Daws' statement that "There is a risk that the United Nations will be weakened by an expansion of the membership of the UN Security Council. There is an equal risk that it will be weakened by the maintenance of the status quo",142 undergirds the need for a balanced field of studies of UNSC reform.

To balance the two main lines of thinking regarding a reform, the notion of convergence might be a source of inspiration. During the 7oth UNGA, the IGN produced a document on 'The Elements of Convergence.' ${ }^{143}$ The content described how the IGN had managed to agree upon a set of particular convergences concerning two out of the five official vital areas of reform focus (A/62/557), as designated in $2008 \mathrm{GA}$. The two areas were 1) The relationship between the Council and the General Assembly, and 2) The size of an enlarged Council and the working methods of the Council. Managing to produce a document with agreements on paper was a "significant step forward". ${ }^{144}$ Not the least because of the opposition in place during the negotiations, but also because certain powerful countries felt that the previous year's negotiations had led to a document which was too specific. Most importantly, the convergence paper includes that the council's membership should be expanded to between twenty-one and twenty-seven seats. Cilliers, is sceptical concerning any impact from 'The Elements of Convergence,' and sees the potential of the

\footnotetext{
141 Paul, Of Foxes and Chickens-Oligarchy and Global Power in the UN Security Council, 160.

142 Daws, "Security Council Reform: The Dual Risks," 1.

143 The President of the General Assembly, "Statement by the President of the General Assembly," 2016.

144 Langmore and Thakur, "The Elected but Neglected Security Council Members," 105.
} 
IGN's work leading to a reform as being non-existing. ${ }^{145}$ Regardless of whether the IGN's concluding produce was a success or not, inspiration can be drawn from Luck's observance that in the UN "[...] political convergence precedes institutional change and not the other way around", ${ }^{146}$ and consequently aim for elements of convergence within academia between structural and working methods reform advocacies.

Perhaps, research could start by agreeing with Nadin, that member states should drop their maximalist positions. ${ }^{147}$ Correspondingly, scholars could look to the significance of the African group's (maximalist) calls for expansion of both types of council seats. It is close to impossible to achieve the needed two-thirds support for charter amendments from the GA without including the fifty-four African states - the kingmakers according to Nadin.

Researchers that want to pump fresh blood into the debate could look into the internal disagreements within the African Group about which African states should be granted permanent council seats. ${ }^{148}$ This political feature can be utilised to reconsider approaches to the group's demands for permanent African seats with veto rights. Correspondingly, analyses could investigate how African countries, which also represents The Global South, could be catered to in a manner that would strengthen their own, as well as others' views of the council's legitimacy. Perhaps, there is potential in seeking a higher number of both types of African seats than those proposed in the Ezulwini Consensus, ${ }^{149}$ as a way to dissipate the calls for African veto rights. The Ezulwini paper calls for permanent African seats with veto rights, but at the same time mentions that the African Union is opposed to the principle of the veto. It could be possible that this paradox of a stance is an open door for mediation. Structural reform without veto expansion could help prevent a $\mathrm{P}_{5}$ interception and forced landing of the process. Moreover, it seems as if many African countries are more interested in having increased influence when it comes to peacekeeping missions on the African continent, than they are in obtaining the veto right.

Any country that currently possesses a veto right (excluding France and the UK because they have stopped using theirs) are essentially able to prevent the global community from acting against its national interest. The veto system then, is more a reflection of the geopolitical strengths of USA, Russia, and

\footnotetext{
145 Cilliers, "Global Trends Analysis," 7.

146 Luck, "How Not to Reform the United Nations," 410-11.

147 Nadin, UN Security Council Reform, 117.

148 Lydia Swart and Cile Pace, "Changing the Composition of the Security Council: Is There a Viable Solution?," Center for UN Reform Education, no. March (2015).

149 The African Unions common position on UNSC reform from 2005.
} 
China, than it is instrumental in reinforcing them. Therefore, when academics present their preferences for UNSC reform, we could perhaps point out, that no one member state can presently measure up to the military status of USA, Russia or China. ${ }^{150}$ Consequently, the addition of veto rights to more countries would be a symbolic act more than a measure of equalising the current zenith of global power. There is no need to write of that even as a status symbol; the veto remains in high demand. However, being present in the same group as those currently possessing the veto is, as mentioned, likely perceived by aspirants for council membership, as immensely valuable. ${ }^{151}$

Despite all the debates and rounds of negotiations in the $\mathrm{UN}$, all the research, and suggestions on reform from academia, the issue remains unresolved. The proposed notion of convergence between the two lines of thinking found in academia is meant as an inspiration for the investigation of new approaches. ${ }^{152}$ Luck was surely right when he wrote that the proponents of structural reform need to do better in explaining how an expanded council would perform better, and those opposing structural reform in answering if no structural reform now, then when would the time be ripe?153 Therefore, research is needed that aligns the widespread quest for structural reform among member states with the critical observations from academia about the need to pay attention to how reform will impact the efficiency of the council.

150 Einsiedel, Malone, and Ugarte, "Conclusion: The Security Council and a World in Crisis," 867; David L Bosco, Five to Rule Them All: The UN Security Council and the Making of the Modern World (Oxford: Oxford University Press, 2009), 3.

151 Ilyana Kuziemko and Eric Werker, "How Much Is a Seat on the Security Council Worth? Foreign Aid and Bribery at the United Nations," Journal of Political Economy 114, no. 5 (2006): 905-28; James Raymond Vreeland and Axel Dreher, The Political Economy of the United Nations Security Council: Money and Influence, ed. James Raymond Vreeland (New York, N.Y.: Cambridge University Press, 2014).

152 Edward De Bono, Lateral Thinking: An Introduction (London: Vermilion, 2014).

153 Luck, UN Security Council -Practice and Promise, 1:126. 